\title{
Implementing the Golden Hour Protocol to Improve the Clinical Outcomes in Preterm Infants
}

Seong Hee Jeong, $\mathrm{MD}^{1}$, Mun Hui Jeong, $\mathrm{MD}^{1}$, Su Jeong Park, $\mathrm{MD}^{2}$, Narae Lee, $\mathrm{MD}^{1}$, Mi Hye Bae, MD², Young Mi Han, $\mathrm{MD}, \mathrm{PhD}^{1}$, Kyung Hee Park, $\mathrm{MD}, \mathrm{PhD}^{2}$, and Shin Yun Byun, $\mathrm{MD}, \mathrm{PhD}^{1}$

${ }^{1}$ Department of Pediatrics, Pusan National University Children's Hospital, Pusan National University School of Medicine, Yangsan, Korea ${ }^{2}$ Department of Pediatrics, Pusan National University Hospital, Pusan National University School of Medicine, Busan, Korea

\section{ABSTRACT}

Purpose: Since premature infants are sensitive to the changes in blood glucose levels and body temperature, maintaining these parameters is important to avoid the risk of infections. The authors implemented the Golden Hour protocol (GHP) that aims to close the final incubator within one hour of birth by implementing early treatment steps for premature infants after birth, such as maintaining body temperature, securing airway, and rapidly administering glucose fluid and prophylactic antibiotics by securing breathing and rapid blood vessels. This study investigated the effect of GHP application on the short- and long-term clinical outcomes.

Methods: We retrospectively analyzed the medical records between 2017 and 2018 before GHP application and between 2019 and 2020 after GHP application in preterm infants aged 24 weeks or older and those aged less than 33 weeks who were admitted to the neonatal intensive care unit.

Results: Overall, 117 GHP patients and 81 patients without GHP were compared and analyzed. Peripheral vascularization time and prophylactic antibiotic administration time were shortened in the GHP-treated group $(P=0.007$ and $P=0.008)$. In the shortterm results, the GHP-treated group showed reduced hypothermia upon arrival at the neonatal intensive care unit $(P=0.002)$, and the blood glucose level at 1 hour of hospitalization was higher $(P=0.012)$. Furthermore, the incidence of neonatal necrotizing enteritis decreased $(P=0.043)$. As a long-term result, the incidence of BPD was reduced $(P=0.004)$.

Conclusion: We confirmed that applying GHP improved short- and long-term clinical outcomes in premature infants aged $<33$ weeks age of gestation, and we expect to improve the treatment quality by actively using it for postnatal treatment.

Key Words: Infant, premature; Golden Hour protocol; Quality improvement
Received: 26 December 2021

Revised: 15 February 2022

Accepted: 15 February 2022

Correspondence to: Shin Yun Byun, $\mathrm{MD}, \mathrm{PhD}$

Department of Pediatrics, Pusan National University Children's

Hospital, Pusan National University School of Medicine, 20 Geumo-ro, Mulgeum-eup, Yangsan 50612, Korea

Tel: +82-55-360-2180

Fax: $+82-55-360-2181$

E-mail: byun410@hanmail.net

Copyright(c) 2022 By Korean Society of Neonatology

This is an Open-Access article distributed under the terms of the Creative Commons At tribution Non-Commercial License (http:// creativecommons.org/licenses/by-nc/4.0), which permits unrestricted non-commercial use, distribution, and reproduction in any medium, provided the original work is pro perly cited. 
서론

신생아집중치료실의 의료 수준이 발달함에 따라 초극소 미숙아 의 생존율이 증가하였고 이에 따라 생존아의 단기적, 장기적 합병증 은 증가하고 있다 ${ }^{1-3)}$. 미숙아 출생은 신생아 사망의 주요 원인으로 만삭아보다 저체온, 저혈당, 감염에 노출되기 쉬워 출생 후 체온과 호흡 유지, 영양 및 감염 관리는 모든 신생아집중치료실에서 중요하 게 여기는 기본 관리이단).

Cowley 등')이 처음 발표한 'Golden Hour (GH)' 의 개념은 성인 에게 외상성 문제가 생겼을 때 초기 의학적 처치 1 시간을 의미하며, 이는 환자의 사망률을 감소시키고 장기적 예후에 긍정적인 영향을 미쳐 환자의 생명에 매우 중요한 시간이다. 이를 참고하여 2007년 Reynolds 등( 최초로 미숙아 처치에 GH 개념을 적용하여 구체적 인 흐름도를 제시하였고 28 주 미만, $1,500 \mathrm{~g}$ 미만의 미숙아에게 적 용하여 출생 1 시간 이내 체온, 혈당, 호흡 안정화를 위해 필요한 처 치를 시행하여 결과적으로 미숙아 망막증과 기관지폐 형성이상이 감소된 것을 발표하였다. 이후 미숙아의 출생 후 기본 처치를 1 시간 이내 시행하여 단기적, 장기적 예후 향상을 증명한 Golden Hour protocol (GHP) 적용에 관한 연구들이 활발히 이루어져 왔다7-16).

미숙아를 대상으로 GHP를 적용하여 임상적 결과를 비교한 국내 연구는 보고된 적 없어 저자들은 33 주 미만 미숙아에게 GHP를 적 용하여 단기적 및 장기적 임상 결과에 대한 영향을 알아보고, 질 향 상을 위해 실제 임상에서 개선할 부분이 있는지 알아보고자 하였다.

\section{대상 및 방법}

\section{1. 연구대상 및 디자인}

2017년 1월부터 2020년 12월까지 4년간 본원에서 출생하여 신생아집중치료실에 입원한 24 주 이상, 33주 미만 미숙아 198명 을 대상으로 하였고, 심각한 선천성 기형을 동반한 미숙아 18 명은 제외하였다. 2017-2018년 GHP를 적용하지 않은 81명과 20192020 년 GHP를 적용한 117 명의 두 군으로 나누어 임상적 특징, 입 원 후 초기 처치를 마친 시간, 단기적 및 장기적 결과를 후향적으로 조사하였다.

\section{Golden Hour protocol 적용}

미숙아 출생 후 호흡, 체온, 영양, 감염 관리의 기본 처치 후 인큐 베이터 뚜껑을 닫는 데까지 걸리는 시간을 1 시간 이내로 하겠다는 목표를 가진 GHP를 적용하였고, 분만실과 수술실에서 출생한 미 숙아가 신생아집중치료실로 입실 시와 모든 처치가 끝난 후 체온을 조사하였다. GHP 적용 전에는 전공의에게 적극적인 분만 참여, 담
당 간호사 1 명 배치, 환자 도착 후 기계 호흡기와 중심혈관정맥 준 비물 세팅을 하였고, 항생제 처방을 내고 약국에서 항생제를 가지 고 오도록 하였다. 중심 난방 시스템으로 적정 환경 온도가 환자 도 착 시 맞춰지지 않은 경우가 있었고, 급속 분만 시에는 인큐베이터 온도가 맞춰지지 않는 경우가 있었다. 라인 확보가 되지 않을 경우 여러 번 시도하면서 소요되는 시간이 있었고, 당직 시간 미숙아 출 생 시에는 전공의 1 명이 분만, 입원 후 처치를 해야 하는 경우도 있 었다. 이에 대한 문제점들을 파악하여 GHP 적용 후에는 미숙아 출 생 시 숙련된 소아청소년과 의사나 신생아 전문의가 분만에 함께 참 여하여 전공의 저년차가 분만에 적극적으로 참여하여 발생할 수 있 는 처치 시간 지연을 줄였고, 초극소 저체중출생아일 경우에는 분 만 가기 전 기계호흡, 배꼽정맥 준비물, 항생제를 미리 준비해 두었 다. 출생 후 분만장에서의 의료진 판단 후 미숙아의 호흡 상태에 따 라 양압 환기 또는 기관 삽관 후 신생아중환자실 도착 후 바로 호흡 기 적용, 모든 미숙아에게 수분, 열량, 전해질, 아미노산 투여를 위 하여 미숙아 출생 시에는 고년차 간호사가 말초혈관확보를 하도록 하여 혈관확보 시간의 단축을 기대하였다. 초극소 저체중출생아일 경우에는 담당 간호사를 기존 1 명에서 2 명으로 증원하여 간호 처치 하도록 하였다. 소아청소년과 의사가 확보한 중심 혈관으로 모든 미 숙아에게 수액 투여, 출생 후 산소 공급이 필요한 경우는 선천성 폐 렴 가능성을 배제하기 위하여 예방적 항생제를 투여하였고, 처치하 는 의사, 처방 내는 의사를 지정하여 처치하는 동안 처방이 지연되 는 것을 방지하였다. 응급 분만 시를 대비하여 온도, 습도가 맞춰진 인큐베이터 하나는 구비해 두었고, 이동용 히터기를 구동하여 적정 환경 온도가 신속히 맞춰지도록 하였다. 모든 처치가 끝난 후 인큐 베이터 뚜껑을 닫았고 처치가 시행되는데 소요된 시간은 담당 간호 사가 기록하였다(Figure 1).

\section{3. 자료 수집}

연구 기간에 입원한 미숙아 198 명의 임상적 특징으로는 재태기 간, 출생체중, 성별, 분만방식, 입원 시 기관 삽관 후 호흡기 적용 또 는 양압환기 적용 여부, 배꼽관 삽입 여부에 대하여 조사하였다. 본 원은 제왕 절개를 시행하는 수술방과 자연 분만을 시행하는 분만실 에서 신생아집중치료실 도착까지 소요되는 시간이 각각 약 5 분, 1 분으로 이동 시간의 차이가 있어 이를 고려하여 신생아 중환자실 도 착 시간을 기준으로 분석하였다. GHP 적용 전후 기본 처치를 하는 데 걸리는 시간을 조사하기 위해 출생 후 신생아집중치료실에 도착 시간, 기관 삽관 및 양압환기 적용 시간, 아기에 대한 처치, 처방 입 력 시간, 말초 정맥관 삽입 시간, 배꼽관 삽입 시간, 초기 예방적 항 생제 시작 시간, 마지막으로 인큐베이터 문을 닫기까지 걸린 시간 을 조사하였다.

입원 후 한 달을 기준으로 단기적 및 장기적 임상 결과의 지표를 
나누었다. 단기적 임상 결과로는 입원 당시와 입원 1 시간 후 $36.5^{\circ} \mathrm{C}$ 미만의 저체온, $40 \mathrm{mg} / \mathrm{dL}$ 이하의 저혈당 발생 여부를 조사하였고, 입원 1 시간에 시행한 혈당 검사 수치를 비교하였고, 입원 1 시간 이 내에 인큐베이터 뚜껑이 닫히는 것이 실행되는지 여부를 비교하였 다. 입원 1 주 이내 신생아 조기 패혈증을 확인하기 위하여 염증반 응수치(C-reactive protein, $\mathrm{CRP}$ )가 $1 \mathrm{mg} / \mathrm{dL}$ 이상으로의 상승 이 있었는지, 생후 1 일, 3 일, 7 일에 시행한 혈액배양검사에서 균 동 정 여부를 확인하였고, 산모의 조기 양막 파수 여부, 발열, 빈맥 등 산모의 임상증상, 백혈구 증가증, $\mathrm{CRP}$ 증가 여부, 질 분비물 배양 검사 결과 자료 등을 분석하여 산모 위험인자에 대하여 조사하였다. 결찰술을 시행한 동맥관 개존증, modified Bell's staging criteria 3 기 이상으로 수술을 시행한 괴사성 장염을 비교하였고, 동맥관 개 존증의 수술 기준은 환자의 임상 소견과 심장초음파 소견으로 혈역

\section{$<$ Golden Hour Protocol worksheet>}

\begin{tabular}{|l|l|l|l|l|l|}
\hline \multicolumn{2}{|c|}{ Patient information } & \multicolumn{2}{c|}{ Measurement } & IV Fluid & Time \\
\hline Name & & Weight & & D10W & \\
\hline ID & & Height & & TPN & \\
\hline GA & & $\begin{array}{l}\text { Head } \\
\text { circumstance }\end{array}$ & & & \\
\hline Multiple & $1 / 2 / 3$ & $\begin{array}{l}\text { Chest } \\
\text { circumstance }\end{array}$ & & & \\
\hline Birthday & & & & $\begin{array}{l}\text { Time to X-ray } \\
\text { displayed }\end{array}$ & \\
\hline Sex & M/F & & & & \\
\hline
\end{tabular}

\begin{tabular}{|l|l|l|l|}
\hline & Time & Medication & Time \\
\hline Birth & & Eye oint & \\
\hline Arrival at NICU & & Vit K & \\
\hline Stat order form sent & & Ampicillin & \\
\hline $\begin{array}{l}\text { Intubation \& } \\
\text { Ventilator apply }\end{array}$ & & Gentamicin & \\
\hline CPAP apply & & & \\
\hline Peripheral IV Access & & $\begin{array}{l}\text { 口check here if antibiotics } \\
\text { start after } 1 \mathrm{hr} \text { after } \\
\text { admission. }\end{array}$ \\
\hline UA,UV started & & & \\
\hline UA,UV placed & & & \\
\hline Incubator closed & & & \\
\hline $\begin{array}{l}\text { Goal humidity } \\
\text { reached }\end{array}$ & & & \\
\hline
\end{tabular}

\begin{tabular}{|c|c|c|c|c|c|c|c|}
\hline \multicolumn{7}{|c|}{ Vital signs flowsheet } \\
\hline & BT & HR & RR & BP & FiO2 & SpO2 & BST \\
\hline At admission & & & & & & & \\
\hline After $1 \mathrm{hr}$ & & & & & & & \\
\hline
\end{tabular}

\section{Discussion : If Golden Hour failed, list reasons.}

Figure 1. Golden Hour protocol worksheet at admission neonatal intensive care unit (NICU). This worksheet was used as the data collection tool for this project. Abbreviations: IV, intravenous; TPN, total parenteral nutrition; GA, gestational age; CPAP, continuous positive airway pressure; UA, umbilical artery; UV, umbilical vein; $\mathrm{BT}$, body temperature; $\mathrm{HR}$, heart rate; $\mathrm{RR}$, respiratory rate; $\mathrm{BP}$, blood pressure; BST, blood sugar test.
학적 의미가 있다고 평가되어 약물적 치료를 시행했으나 반응이 없 는 경우로 하였다.

입원 한 달 이후 장기적 임상 결과로 산소를 중단한 시기와 퇴원 시 교정 주수를 비교하였고, 하루 체중당 $120 \mathrm{cc}$ 이상 정맥영양수 액 없이 완전 장관 영양에 도달한 시기를 알아보았다. 3 단계 이상의 뇌실내출혈, 뇌실 주위 백질연화증, 레이저 수술이 필요한 미숙아 망막증, 기관지폐 형성이상으로 이환된 환자수와 사망률을 조사하 였다. 기관지폐 형성이상은 생후 28 일 이상 산소 치료가 필요한 환 자들로 분류하였고 교정 나이 36주에 투여되는 호흡 보조의 종류, 공급되는 산소 농도에 따른 경증, 중등증, 중증으로 세분화는 하지 않았다미.

\section{4. 통계 분석}

통계 분석은 IBM SPSS statistics version 22 (IBM Co., Armonk, NY, USA)를 사용하였고, 연속형 변수의 경우 독립표본 $t$-검정테스트를 이용, 범주형 변수는 카이제곱을 통하여 통계량을 분석하였으며 $P$-value가 0.05 미만일 때 통계학적으로 유의한 차 이가 있다고 판단하였다.

\section{결과}

\section{1. 환자 특성}

재태주수 24 주 이상 33 주 미만의 미숙아 198 명이 연구에 포함되 었고 81 명은 $\mathrm{GHP}$ 미적용군, 117 명은 $\mathrm{GHP}$ 적용군이었다. 두 군의 재태주수, 출생체중, 성별은 유의한 차이가 없었으나 재태 주수는 30 주 이상 32 주 미만, 출생 체중은 $1 \mathrm{~kg}$ 이상 $1.5 \mathrm{~kg}$ 미만 환아가 가 장 많은 비율을 차지하였다. GHP 미적용군에 비하여 적용군에서 제왕절개 분만의 비율이 증가하였고 입원 시 기관삽관 또는 양압환 기를 적용한 환자 수도 증가하였으나 두 군 간의 유의한 차이는 없 었다. 배꼽관을 삽입한 환아는 $\mathrm{GHP}$ 적용군에서 유의하게 적었다 $(P=0.048)$ (Table 1$)$.

\section{GHP 적용 전 후 항목별 소요 시간의 비교}

$\mathrm{GHP}$ 적용군에서 출생 후 신생아집중치료실로 이동시간이 유의 하게 길었으나(P=0.001) 이는 GHP가 적용된 2019-2020년 분만 장보다 거리가 먼 제왕절개 수술의 비율이 높았기 때문이다. 기관삽 관 후 호흡기 적용이나 양압환기 적용하는 시간, 입원 처치, 처방 입 력 시간, 배꼽관 삽입 시간은 두 군 간의 유의한 차이가 없었으며, 말초혈관 확보 시간은 의미 있게 감소하였다 $(P=0.007)$. 혈관 확보 시간이 단축되며 항생제 첫 투여 시간도 의미 있게 감소하여 미숙아 들에게 예방적 항생제를 더 빨리 시작할 수 있었다 $(P=0.008)$. 신생 
Table 1. Clinical Characteristics of Pre- and Post-Golden Hour Protocol Preterm Infants

\begin{tabular}{lccc}
\hline Characteristic & $\begin{array}{c}\text { Pre-GHP } \\
(\mathrm{n}=81)\end{array}$ & $\begin{array}{c}\text { Post-GHP } \\
(\mathrm{n}=117)\end{array}$ & $P$-value \\
\hline Gestational age (wk) & $16(19.7)$ & $20(17.7)$ & 0.772 \\
$24-26$ & $22(27.1)$ & $31(26.1)$ & 0.953 \\
$27-29$ & $43(53.0)$ & $66(56.4)$ & 0.751 \\
$30-32$ & & & \\
Birthweight (g) & $21(25.9)$ & $31(26.4)$ & 0.945 \\
$<1,000$ & $30(37.0)$ & $45(38.4)$ & 0.956 \\
$1,000-1,499$ & $29(35.8)$ & $41(35.0)$ & 0.967 \\
$1,500-2,499$ & $1(1.2)$ & 0 & 0.853 \\
$\geq 2,500$ & $40(49.4)$ & $69(59.0)$ & 0.183 \\
Male sex & & & \\
Delivery type & $27(33.3)$ & $28(23.9)$ & 0.196 \\
NSVD & $54(66.7)$ & $89(76.1)$ & 0.197 \\
C-section & $58(71.6)$ & $87(74.4)$ & 0.964 \\
Intubation at admission & $6(7.4)$ & $13(11.1)$ & 0.532 \\
SNIPPV at admission & $32(49.5)$ & $32(27.4)$ & 0.048 \\
Umbilical catheter insertion & & & \\
\hline
\end{tabular}

Values are expressed as number (\%).

Abbreviations: GHP, Golden Hour protocol; NSVD, normal spontaneous vaginal delivery; C-section, cesarean delivery; SNIPPV, synchronized nasal intermittent positive pressure ventilation.

아집중치료실 입실 후 기본 처치를 끝내고 최종 인큐베이터를 닫은 시간은 $59.4 \pm 0.5$ 분에서 $51.8 \pm 0.4$ 분으로 $\mathrm{GHP}$ 적용군에서 더 빨 랐으나 통계학적으로 유의한 차이는 없었다(Table 2).

\section{GHP 적용 전후의 단기적 결과}

신생아집중치료실 도착 시 저체온이 확인된 환자 수는 유의하게 감소하였고 $(P=0.002)$, 입원 1 시간에 저체온을 나타내는 환자 수는 GHP 적용 후 감소하였으나 유의한 차이는 없었고, 인큐베이터 뚜 껑이 1 시간 이후에 닫힌 환자 수는 $\mathrm{GHP}$ 적용 후 감소하였으나 통 계학적으로 유의하지 않았다. 입원 시와 1 시간 후 저혈당 빈도는 차 이가 없었으나 혈관 확보가 더 빨랐던 GHP 적용 군에서 입원 1시 간의 평균 혈당이 유의하게 증가하였다 $(P=0.012)$. 입원 1 주 이내에 시행한 혈액검사에서 염증반응은 차이가 없었고 조기 패혈증은 감 소하였으나 통계학적으로 유의하지 않았으며 산모 위험인자를 비 교하였을 때 두 군 간의 차이가 없었고, 동맥관 개존증 환자는 GHP 시행군에서 감소하였으나 유의한 차이가 없었고, 괴사성 장염 환자 는 유의하게 감소하였다 $(P=0.043)$ (Table 3).

\section{GHP 적용 전후의 장기적 결과}

$\mathrm{GHP}$ 적용 후 신생아집중치료실 퇴원 시점과 산소 투여 중단 시 기의 교정 주수가 빨라졌으나 통계학적으로 유의한 차이는 없었다.
Table 2. Comparison of Time between Pre- and Post-Golden Hour Protocol Preterm Infants

\begin{tabular}{|c|c|c|c|}
\hline Time (min) & $\begin{array}{c}\text { Pre-GHP } \\
(\mathrm{n}=81)\end{array}$ & $\begin{array}{c}\text { Post-GHP } \\
(\mathrm{n}=117)\end{array}$ & $P$-value \\
\hline Arrival at NICU after birth & $12.5 \pm 0.6$ & $15.5 \pm 0.1$ & 0.001 \\
\hline Intubation or CPAP apply & $11.0 \pm 0.11$ & $10.8 \pm 0.2$ & 0.914 \\
\hline Stat order form sent & $20.4 \pm 0.1$ & $21.7 \pm 0.1$ & 0.339 \\
\hline Peripheral IV access & $48.7 \pm 0.3$ & $35.6 \pm 0.2$ & 0.007 \\
\hline Umbilical catheter insertion & $77.5 \pm 0.8$ & $85.7 \pm 0.9$ & 0.668 \\
\hline Administration of antibiotics & $124.2 \pm 2.2$ & $99.9 \pm 0.5$ & 0.008 \\
\hline Close of incubator top & $59.4 \pm 0.5$ & $51.8 \pm 0.4$ & 0.785 \\
\hline
\end{tabular}

Values are expressed as mean \pm standard deviation.

Abbreviations: GHP, Golden Hour protocol; NICU, neonatal intensive care unit; CPAP, continuous positive airway pressure; IV, intravenous.

Table 3. Comparison of Short-Term Clinical Outcomes According to Implementation of Golden Hour Protocol in Preterm Infants

\begin{tabular}{|c|c|c|c|}
\hline Variable & $\begin{array}{c}\text { Pre-GHP } \\
(\mathrm{n}=\mathbf{8 1})\end{array}$ & $\begin{array}{c}\text { Post-GHP } \\
(\mathrm{n}=117)\end{array}$ & $P$-value \\
\hline \multicolumn{4}{|l|}{ Hypothermia } \\
\hline At admission & $42(51.9)$ & $34(31.6)$ & 0.002 \\
\hline 1 hour after admission & $15(18.5)$ & $11(9.4)$ & 0.098 \\
\hline \multicolumn{4}{|l|}{ Hypoglycemia } \\
\hline At admission & $13(16.1)$ & $21(17.9)$ & 0.875 \\
\hline 1 hour after admission & $8(9.9)$ & $6(5.1)$ & 0.318 \\
\hline $\begin{array}{l}\text { Blood sugar } 1 \text { hour after } \\
\text { admission }(\mathrm{mg} / \mathrm{dL})\end{array}$ & $60 \pm 22.6$ & $68 \pm 23.8$ & 0.012 \\
\hline Incubator close time over 1 hour & $23(28.4)$ & $20(17.1)$ & 0.085 \\
\hline $\begin{array}{l}\text { CRP rising within } 1 \text { week after } \\
\text { admission }(>1 \mathrm{mg} / \mathrm{dL})\end{array}$ & $15(13.5)$ & $16(13.7)$ & 0.393 \\
\hline Proven early sepsis & $6(18.5)$ & $3(2.6)$ & 0.056 \\
\hline PDA & $11(13.6)$ & $14(12.0)$ & 0.782 \\
\hline NEC & $10(12.3)$ & $8(6.8)$ & 0.043 \\
\hline
\end{tabular}

Values are expressed as number (\%) or mean \pm standard deviation. Abbreviations: GHP, Golden Hour protocol; CRP, C-reactive protein; PDA, patent ductus arteriosus; NEC, necrotizing enterocolitis.

완전 장관영양에 도달한 시기도 단축되었지만 두 군 간의 유의한 차 이는 없었으며 3단계 이상의 뇌실내출혈, 뇌실 주위 백질연화증, 미 숙아 망막증도 두 군 간의 차이는 없었다. GHP 적용군에서 기관지 폐 형성이상의 이환율은 유의하게 감소하였으며 $(P=0.004)$ 사망률 은 차이가 없었다(Table 4).

\section{고찰}

본 연구는 미숙아 초기 처치의 질 향상을 위해 재태기간 24 주 이 상 33 주 미만 미숙아에게 GHP를 적용하여 분만 후 호흡 및 혈관 확 
Table 4. Comparison of Long-Term Clinical Outcomes According to Implementation of Golden Hour Protocol in Preterm Infants

\begin{tabular}{|c|c|c|c|}
\hline Variable & $\begin{array}{c}\text { Pre-GHP } \\
(\mathrm{n}=81)\end{array}$ & $\begin{array}{c}\text { Post-GHP } \\
(\mathrm{n}=117)\end{array}$ & $P$-value \\
\hline PMA of discharge home & $39.9 \pm 4.1$ & $38.6 \pm 4.3$ & 0.072 \\
\hline PMA of O2 supply stop & $36.6 \pm 2.8$ & $36.4 \pm 2.6$ & 0.795 \\
\hline GA reaching full enteral feeding & $35.1 \pm 3.2$ & $33.6 \pm 3.3$ & 0.412 \\
\hline IVH ( $\geq$ grade III) & $3(3.7)$ & $6(5.1)$ & 0.307 \\
\hline PVL & $5(6.2)$ & $11(9.4)$ & 0.331 \\
\hline ROP ( $\geq$ grade III) & $9(11.1)$ & $18(15.4)$ & 0.285 \\
\hline BPD & $39(48.1)$ & $31(26.5)$ & 0.004 \\
\hline Death & $8(9.9)$ & $12(10.3)$ & 0.915 \\
\hline
\end{tabular}

Values are expressed as mean \pm standard deviation or number (\%). Abbreviations: GHP, Golden Hour protocol; PMA, postmenstrual age; GA, gestational age; IVH, intraventricular hemorrhage; PVL, periventricular leukomalacia; ROP, retinopathy of prematurity; BPD, bronchopulmonary dysplasia.

보 뒤 항생제 주입까지 마치고 인큐베이터를 1 시간 이내 닫는 것을 목표로 하여 이것이 단기적 및 장기적 예후에 어떤 영향을 미치는지 알아보고자 하였다.

$\mathrm{GHP}$ 를 적용하고 난 뒤 아기 출생 후 신생아집중치료실까지 도착 시간이 의미 있게 길어졌으나 이는 연구 기간의 차이로 고위험 산모 신생아 통합치료 센터 지정 후 2017-2018년보다 2019-2020년 선천 소아심장병을 포함한 기형아 빈도가 높아져 제왕절개로 분만 한 경우가 증가하여 그런 것으로 생각되며 환자 처치에 차이는 없었 다. GHP를 시작하고 나서 다들 1 시간 이내 인큐베이터를 닫는 것 을 목표로 처치를 하니 호흡 확보 및 입원 처방 입력 시간은 차이가 없었으나 말초혈관 확보가 빨라져 예방적 항생제 투여가 빨라졌다. 1 시간 이내 인큐베이터를 닫은 시간은 의미 있는 차이는 없었으나 $\mathrm{GHP}$ 적용 후 $59.4 \pm 0.5$ 분에서 $51.8 \pm 0.4$ 분으로 감소하여 아기의 빠른 안정을 위해 모두 노력하였음을 알 수 있었다. GHP 적용 후 신생아집중치료실 정책을 수정하여 배꼽관 삽입을 줄이고 말초 삽 입 중심 정맥관을 더 사용하여 이전에 비해 배꼽관 삽입한 미숙아의 수가 현저히 줄고 26주 미만에서 배꼽관 삽입을 주로 시행하니 오 히려 GHP 적용 후 배꼽관 삽입을 마치기까지의 시간은 연장되었으 나 통계학적으로 의미는 없었다.

$\mathrm{GHP}$ 적용 전후 단기적 임상 결과를 비교하였을 때 입원 시 저체 온의 비율이 의미 있게 감소하였는데, 신생아집중치료실로 입원한 초극소 저체중 출생아에서 저체온의 발생률은 31\%-78\%로 저체온 시 폐혈관 저항, 뇌혈관 흐름에 변화를 주며, 저혈당, 저산소증, 산 염기 불균형, 저혈압과 저혈량증을 초래하며, 젖산의 축적으로 뇌 세포를 포함한 전신 세포를 손상시킬 수 있고 이로 인하여 사망률 을 증가시킬 수 있어17-19) 저체온 예방은 매우 중요하다. 미숙아 출 생 시 분만실과 수술실에게 최적의 환경 온도를 당부하였으나 미숙
아 분만은 응급 분만이 많아 실제 분만실에 들어갔을 때 최적의 온 도가 맞춰져 있지 않은 경우가 많았다. 저자들은 GHP 적용 후 1 시 간 이내 미숙아를 정상체온으로 유지하기 위해 분만실과 수술실에 게 최적의 환경 온도를 더욱 철저하게 공지, 점검하였고, 분만 결정 시 즉시 재공지, 확인하였고 이동용 히터도 추가하여 빠른 시간에 환경 온도를 올릴 수 있도록 하였고 $1 \mathrm{~kg}$ 미만 미숙아는 출생 후 비 닐백으로 감싸서 신생아집중치료실 이동 중에 발생할 수 있는 열 손 실을 최소화하였다. 입원 1 시간째 저체온 환자의 비율도 감소하였 는데 이는 배꼽관 삽입 빈도와 말초혈관 삽입 시간이 유의미하게 단 축되어 인큐베이터를 GHP 적용 전보다 더 빨리 닫을 수 있어 가능 했지만, 통계학적으로 의미는 없었다. 저자들은 GHP 적용 후 환자 담당 간호사와 다르게 말초혈관 확보는 함께 근무하는 가장 고년차 간호사가 시도하도록 하여 여러 번의 시도로 인한 자극과 혈관 확 보 시간의 지연을 방지하였다. Castrodale와 Rinehart")는 GH를 위해 분만장에서 배꼽 정맥을 확보한 후 신생아집중치료실로의 이 동을 목표로 하였고 이는 입원 후 말초혈관 확보를 위한 시간을 절 약하여 당분, 아미노산 포함 수액과 예방적 항생제가 빠르게 투여 됨으로써 혈당 안정화, 감염 예방에 긍정적인 영향을 끼쳤으나 분 만장에서 배꼽 정맥 확보 과정 중 무균적 시술 시행 및 성공 여부는 알 수 없었다. 신생아집중치료실 입원 시와 1 시간째 저혈당 빈도는 차이가 없었으나 GHP 적용 후 말초혈관 삽입이 빨라져 수액 공급 이 일찍 시작되며 1 시간째 혈당 수치가 의미 있게 증가하여 저혈당 에 노출이 잘 되는 미숙아의 혈당 안정화에 긍정적 영향을 미쳤음 을 알 수 있었다.

극소 저체중출생아의 경우 조기 패혈증은 1,000 명당 15 명 정도 로 빈도가 높으며 사망으로 이어지므로 조기 항생제 투여는 중요하 다 ${ }^{20)}$. GHP 적용 후 말초혈관 확보 시간이 단축됨에 따라 초기 항생 제 투여가 좀 더 빨리 이루어질 수 있었고 이로 인해 조기 신생아 패 혈증의 빈도가 낮아진 것으로 생각해 볼 수 있었다. 본원에서는 미 숙아 입원 후 항생제 처방을 내면 약국에서 약을 가지고 와야 투여 가 가능하여 첫 항생제가 투여되는 시간을 줄이는 데 한계가 있었 다. 한 논문에서는 약사가 미숙아의 주수, 체중에 맞춰 항생제 처방 을 내도록 허용함으로써 항생제 투약 시작 시간을 단축시켜 담당의 가 환자 처치하는 동안 처방이 늦어 항생제 투여가 지체되는 것을 예방하였고 신속한 항생제 투여로 조기 신생아 패혈증의 발생률을 감소시킬 수 있음을 제시하였다 ${ }^{15,21,22)}$

괴사성 장염은 미숙아에게 발생률이 높은데 이는 장의 운동 및 소 화 능력, 장 혈관의 조절기능, 면역학적 방어능력이 미숙하고 출생 후 저산소증 및 허혈, 저체온, 감염 등의 다양한 인자에 영향을 받 아서 그런 것으로 알려져 있다 ${ }^{23-26)}$. GHP 적용 후 괴사성 장염이 의 미 있게 감소하였는데 이는 빠른 혈관 확보로 인한 수액 공급과 저 체온이 감소하여 전신 상태가 빨리 안정화되어 그런 것으로 생각된 
다. 괴사성 장염이 미숙아의 생존 및 장기적인 삶의 질에 미치는 영 향을 볼 때 $\mathrm{GHP}$ 를 적용함으로 괴사성 장염이 감소한 것은 미숙아 의 단, 장기적 예후에 긍정적인 영향을 미치는 의미 있는 결과라고 생각된다.

GHP 적용 전후 장기적 결과에서 기관지폐 형성이상의 발생이 의 미 있게 감소하였다. 초극소 저체중출생아 출생 시 초기 호흡 확보 를 위한 처치가 잘못되면 폐 실질 손상을 야기하며 기관지폐 형성이 상으로 이행에 직접적인 연관이 있다고 보고되어 있다 ${ }^{27-29)}$. 저자들 은 GHP 적용 후 미숙아 분만 시 숙련된 의료진이 초기 호흡 확보 처 치를 하여 시간을 줄이려고 하였으며, 자가 호흡이 양호한 미숙아는 비침습적 양압환기를 먼저 적용하여 기도 확보 과정에서 생기는 물 리적 자극과, 기계 환기 적용 시 발생 가능한 압력 및 용적 상해로 인 한 폐실질의 손상을 감소시켰다. 또한 장기간 기계호흡으로 인한 폐 손상을 예방하기 위하여 가능한 빠른 기계 환기 이탈을 시도하였다. GHP 전후를 비교해 보았을 때 의미 있는 차이는 없었지만 기관 삽 관 또는 양압환기 적용까지의 시간이 줄었으며, 비침습적 양압환기 의 비율이 높았는데 이런 것들이 기관지폐 형성이상을 감소시킨 원 인이라고 생각된다. $\mathrm{GH}$ 를 적용한 후 뇌실내출혈, 뇌실 주위 백질연 화증, 미숙아 망막증, 사망률의 유의한 감소를 보고한 논문은 많았 으나 본 연구에서는 의미가 없었고 이는 대규모 장기간 연구가 필요 할 것으로 생각된다 $7-16,30,31$.

또한 1 시간 이내에 인큐베이터 뚜껑이 닫히지 못한 미숙아들은 항생제 투여 시간 지연, 배꼽 혈관 확보 시간의 지연이 중요한 이유 였다. 초기 항생제 투여 시간의 지연에는 처방 입력 지연, 항생제 도 착 지연의 문제점이 있었는데 항생제를 신생아집중치료실에 미리 배치하는 방법, 출생 전 예상 체중으로 미리 항생제 용량을 계산해 놓는 방법을 고려해 보았고, 배꼽 혈관 확보 시간의 지연에는 배꼽 혈관 확보 시 숙련된 의료진의 처치 시행과 첫 삽입 수행 실패 시 장 시간 동안 재시행하는 것을 지양하는 방법을 고려해 보았다. 향후 $\mathrm{GHP}$ 적용이 더 좋은 임상적 결과를 가져오기 위해서는 숙련된 의 료진이 기관삽관을 포함한 초기 처치에 적극 관여하여 입원 후 저체 온, 저혈당을 포함한 빠른 안정화를 위해 노력하고 미숙아의 상태가 안 좋아 많은 처치가 필요하여 인큐베이터가 장시간 열려 있어야 할 경우 체온유지를 위하여 중성온도 환경과 습도 조절 방법 등을 보강 하여 저체온을 예방하도록 해야 하겠다.

특히 초극소저체중 출생아일 경우에는 분만 가기 전 미리 기계 호 흡기 설정 완료, 배꼽 혈관 준비물과 예방적 항생제를 미리 준비하 여 오더, 준비, 인편 배송과정에서 소요되는 시간의 단축을 기대해 볼수 있다.

본 연구는 단일 3차 기관에 입원하였던 미숙아 환자들을 대상으 로 GHP 적용군에서 임상적 예후에 어떠한 차이가 있는지와 질 향 상을 위하여 임상에서 개선할 부분이 있는지 알아보고자 하였다. 그
러나 통계학적으로 의미 있게 나온 부분이 한정적으로 도출되고 대 상 환자의 수가 적고 후향적 연구로써 분석하고 해석하는데 제한점 이 있었다. 기관 삽관 시행, 비침습적 양압환기 적용 등에 명확한 기 준이 없었고 임상의의 판단에 근거하여 시행한 처치라 기관지폐 형 성이상 빈도 비교 시 출생 시 호흡 상태를 고려할 수 없었으며 기관 지폐 형성이상을 세분화하여 분석하지 못한 한계가 있다. 또한 본 원 병원 구조상 제왕절개를 시행하는 수술방과 자연분만을 시행하 는 분만실의 거리 차이가 있어 신생아중환자실 도착시간을 기준으 로 처치 시간을 시작하여 통계 분석을 하였던 점에서도 제한점이라 할 수 있다.

결론적으로 저자들은 $\mathrm{GHP}$ 의 적용이 미숙아의 단기적, 장기적 인 예후 향상에 긍정적인 영향을 미침을 확인하였다. 미숙아의 생존 율이 증가함에 따라 이환율도 지속적으로 증가하고 있음을 인지하 고 출생 후 초기 처치의 중요성을 이해하여 GHP를 적용하여 발생 하는 문제점을 인식하고 개선책이 반영된 프로토콜의 개발에 적극 적인 노력을 하여 불필요한 과정을 최소화하고 효율적인 처치에 더 욱 노력해야 하겠다.

\section{ARTICLE INFORMATION}

\section{Ethical statement}

This study was approved by the Institutional Review Board of Pusan National University Yangsan Hospital, and the requirement for informed consent was waived (IRB no. 05-2021-063).

\section{Conflicts of interest}

No potential conflict of interest relevant to this article was reported.

\section{Author contributions}

Conception or design: S.H.J., M.H.J., S.Y.B.

Acquisition, analysis, or interpretation of data: S.H.J., S.J.P., Y.M.H.

Drafting the work or revising: S.H.J., N.L., M.H.B., K.H.P.

Final approval of the manuscript: All authors read and approved the final manuscript.

\section{ORCID}

Seong Hee Jeong https://orcid.org/0000-0003-4811-3103

Mun Hui Jeong https://orcid.org/0000-0002-5073-7276

Su Jeong Park https://orcid.org/0000-0001-7496-7159

Narae Lee https://orcid.org/0000-0002-8281-6550 
Mi Hye Bae https://orcid.org/0000-0001-7168-5084

Young Mi Han https://orcid.org/0000-0002-6120-0490

Kyung Hee Park https://orcid.org/0000-0002-1028-4225

Shin Yun Byun https://orcid.org/0000-0002-9034-5533

\section{Funding}

This work was supported by Pusan National University Research Grant, 2019.

\section{Acknowledgments}

None

\section{REFERENCES}

1. Gleason CA, Juul SE. Avery's diseases of the newborn. 10th ed. Philadelphia: Elsevier Inc., 2018:390-404.

2. Itabashi K, Miyazawa T, Kusuda S, Wada K; Japan Pediatric Society Newborn Committee. Changes in mortality rates among extremely preterm infants born before 25 weeks' gestation: comparison between the 2005 and 2010 nationwide surveys in Japan. Early Hum Dev 2021;155:105321.

3. Zhu Z, Yuan L, Wang J, Li Q, Yang C, Gao X, et al. Mortality and morbidity of infants born extremely preterm at tertiary medical centers in China from 2010 to 2019. JAMA Netw Open 2021;4:e219382.

4. Cloherty JP, Eichenwald EC, Hansen AR, Stark AR. Manual of neonatal care. 7th ed. Philadelphia: Lippincott Williams \& Wilkins, 2015:35-9.

5. Cowley RA, Hudson F, Scanlan E, Gill W, Lally RJ, Long W, et al. An economical and proved helicopter program for transporting the emergency critically ill and injured patient in Maryland. J Trauma 1973;13:1029-38.

6. Reynolds RD, Pilcher J, Ring A, Johnson R, McKinley P. The Golden Hour: care of the LBW infant during the first hour of life one unit's experience. Neonatal Netw 2009;28:211-9.

7. Vento M, Cheung PY, Aguar M. The first golden minutes of the extremely-low-gestational-age neonate: a gentle approach. Neonatology 2009;95:286-98.

8. Annibale DJ, Bissinger RL. The golden hour. Adv Neonatal Care 2010;10:221-3.

9. Castrodale V, Rinehart S. The golden hour: improving the stabilization of the very low birth-weight infant. Adv Neonatal Care 2014;14:9-14.

10. Reuter S, Messier S, Steven D. The neonatal Golden Hour: intervention to improve quality of care of the extremely low birth weight infant. S D Med 2014;67:397-405.

11. Lambeth TM, Rojas MA, Holmes AP, Dail RB. First Golden Hour of life: a quality improvement initiative. Adv Neonatal Care 2016;16:264-72.

12. Sharma D. Golden hour of neonatal life: need of the hour. Matern Health Neonatol Perinatol 2017;3:16.

13. Sharma D. Golden 60 minutes of newborn's life: part 1. Preterm neonate. J Matern Fetal Neonatal Med 2017;30:2716-27.

14. Sharma D, Sharma P, Shastri S. Golden 60 minutes of newborn's life: part 2. Term neonate. J Matern Fetal Neonatal Med 2017;30: 2728-33.

15. Harriman TL, Carter B, Dail RB, Stowell KE, Zukowsky K. Golden hour protocol for preterm infants: a quality improvement project. Adv Neonatal Care 2018;18:462-70.

16. Peleg B, Globus O, Granot M, Leibovitch L, Mazkereth R, Eisen I, et al. "Golden Hour" quality improvement intervention and short-term outcome among preterm infants. J Perinatol 2019; 39:387-92.

17. Bhatt DR, White R, Martin G, Van Marter LJ, Finer N, Goldsmith JP, et al. Transitional hypothermia in preterm newborns. J Perinatol 2007;27 Suppl 2:S45-7.

18. Boo NY, Guat-Sim Cheah I; Malaysian National Neonatal Registry. Admission hypothermia among VLBW infants in Malaysian NICUs. J Trop Pediatr 2013;59:447-52.

19. Hazan J, Maag U, Chessex P. Association between hypothermia and mortality rate of premature infants: revisited. Am J Obstet Gynecol 1991;164(1 Pt 1):111-2.

20. Wang H, Liddell CA, Coates MM, Mooney MD, Levitz CE, Schumacher AE, et al. Global, regional, and national levels of neonatal, infant, and under-5 mortality during 1990-2013: a systematic analysis for the Global Burden of Disease Study 2013. Lancet 2014;384:957-79.

21. Polin RA; Committee on Fetus and Newborn. Management of neonates with suspected or proven early-onset bacterial sepsis. Pediatrics 2012;129:1006-15.

22. Shane AL, Sanchez PJ, Stoll BJ. Neonatal sepsis. Lancet 2017; 390:1770-80.

23. Ford H, Watkins S, ReblockK, Rowe M. The role of inflammatory cytokines and nitric oxide in the pathogenesis of necrotizing enterocolitis. J Pediatr Surg 1997;32:275-82.

24. Hintz SR, Kendrick DE, Stoll BJ, Vohr BR, Fanaroff AA, Donovan $\mathrm{EF}$, et al. Neurodevelopmental and growth outcomes of extremely low birth weight infants after necrotizing enterocolitis. Pediatrics 2005;115:696-703.

25. Prado C, Michels M, Avila P, Burger H, Milioli M, Dal-Pizzol F. The protective effects of fecal microbiota transplantation in an experimental model of necrotizing enterocolitis. J Pediatr Surg 2019;54:1578-83.

26. Tudehope DI. The epidemiology and pathogenesis of neonatal necrotizing enterocolitis. J Paediatr Child Health 2005;41:167-8.

27. Berger TM, Bachmann II, Adams M, Schubiger G. Impact of improved survival of very low-birth-weight infants on incidence 
and severity of bronchopulmonary dysplasia. Biol Neonate 2004;86:124-30.

28. Jobe AH, Bancalari E. Bronchopulmonary dysplasia. Am J Respir Crit Care Med 2001;163:1723-9.

29. Van Marter LJ, Allred EN, Pagano M, Sanocka U, Parad R, Moore $\mathrm{M}$, et al. Do clinical markers of barotrauma and oxygen toxicity explain interhospital variation in rates of chronic lung disease?
The Neonatology Committee for the Developmental Network. Pediatrics 2000;105:1194-201.

30. McGrath JM. Is evidence-based practice routine in the golden hour? J Perinat Neonatal Nurs 2012;26:109-11.

31. Wallingford B, Rubarth L, Abbott A, Miers LJ. Implementation and evaluation of "golden hour" practices in infants younger than 33 weeks' gestation. Newborn Infant Nurs Rev 2012;12:8696. 